\title{
Consumers' Willingness To Pay For Safe Beef In Ibadan-North Local Government, Oyo State, Nigeria
}

\author{
Obi-Egbedi 0. \\ Department of Agricultural Economics \\ University of Ibadan. \\ Ahmed J. \\ Department of Agricultural Economics \\ University of Ibadan. \\ Israel J. M. \\ Department of Agricultural Economics \\ University of Ibadan.
}

\begin{abstract}
Beef demand among urban dwellers in Nigeria has grown overtime with increasing concerns for safety. Beef is commonly sold in open stalls where the risk of contamination is very high. Increasing the quality of beef and other beef products will require improvements on the management of abattoirs as well as inspection and certifications of beef quality. Such improvements will however come at a cost which consumers must be willing to pay. The study therefore assessed consumers' willingness to pay for safe beef in Ibadan Metropolis of Oyo State. Primary data was used for the study and obtained using well-structured questionnaires. Multi-stage sampling was used to select 150 beef consumers. Data were analysed using descriptive statistics and Heckman two-step regression model. Results reveal that majority of beef consumers $(92 \%)$ are aware that beef sold in the open market may be contaminated while about 82\% indicated their willingness to pay for safe beef. Beef consumers are willing to pay an average of $\$ 26.06$ for a kilogramme of certified beef. Consumer's gender and awareness about safe beef significantly influence consumers' willingness to pay for safe beef. The age of the consumer positively influences the amount consumers are willing to pay for safe beef while the household size and frequency of purchase have a negative relationship. The study recommends increased enlightenment programs on safe beef, targeting females by entrepreneurs with respects to advertisements and sales activities while a mechanism of beef certification and quality labelling should also be put in place.
\end{abstract}

Keywords: Heckman, contingent valuation, selectivity, food safety, beef consumers.

\section{INTRODUCTION}

Beef is widely accepted as an important source of protein and staple food in many parts of the world. Globally, it is the third largest produced meat after pig and poultry meats and the second largest traded meat, after poultry meat (FAO, 2014). World beef production is estimated at about 60 million tonnes carcass weight equivalent (CWE), growing at an average of $1.7 \%$ annually (USDA, 2014). This is projected to reach 75 million tonnes CWE by 2023 with an average growth rate of 1.3\% (OECD- FAO Outlook, 2015). The structure of beef production is highly concentrated with ten countries accounting for over $80 \%$ of global output; the United States and Brazil representing 35\% of global production (USDA, 2014). On the other hand, consumption is estimated to be around 58 million tonnes with increased demand driven by the rise in the rate of urbanisation and lifestyle changes due to increased income (USDA, 2014 and Bernard et al., 2009). The USA is the largest beef consumer in the world followed by Brazil 
although; Uruguay accounts for the highest per capita consumption in the world with $49.2 \mathrm{~kg}$. Per capita consumption in the USA and Brazil is about $25.6 \mathrm{~kg}$ (FAO, 2014).

In sub Saharan Africa, Nigeria is both the largest producer and consumer of beef, accounting for about half of total beef consumption in the ECOWAS region (Bernard et al., 2009). The country has an estimated cattle herd of over 19.5 million (NBS, 2012), majority of which are tended by about 8 million nomads. This figure represents about $25 \%$ of the total cattle herd in West Africa (Bernard et al., 2009). An estimated 7.5 million cattle is slaughtered annually in Nigeria to produce roughly 1 million tonnes of carcase beef (GEMS1, 2012). Per capita meat consumption in Nigeria is one of the lowest in the world. It stands at $1.8 \mathrm{~kg}$ per person per year while that of the sub-Saharan Africa region is about $3.3 \mathrm{~kg}$ (FAO, 2014). Demand for beef in Nigeria has been growing due to the increasing rate of urbanisation, consumers' purchasing power and the emergence of a new middle class (Bernard et al, 2009).

Food safety concerns have recently emerged as an important issue among beef consumers in Nigeria, especially in the cities. This is because raw beef sold at different retail points face the risk of contamination due to exposure and contact with microbes from different sources (Umoh, 2002). Food safety issues concerning beef extends from the health and treatment of the live animal, through to slaughtering and final processing into beef and fifth quarter products that is sold to the consumers. Hence, improved management of abattoirs and slaughter houses is an important requirement in efforts to provide beef and beef products that meet quality requirements and that does not endanger public health. Although private beef retail businesses are growing, about $85 \%$ of the trade in beef and beef products in most parts of the country are still conducted in traditional, open market stalls where it is exposed to dust, flies and other environmental pollutants (Bernard et al., 2009). The situation is worsened by overwhelming sanitation problems in markets and abattoirs such as improper refuse disposal, inadequate water supply and gross inadequacy of sanitary facilities. In the absence of standards and quality labels, consumers lack information about the quality of the beef they consume (Ehirim et al 2013). Verbeke and Ward (2006) suggested that information about beef quality can be communicated to consumers through labels and beef certifications. The needs of an increasing number of consumers who want healthier meat from regulated slaughterhouses can be satisfied by the private abattoir sector along with the private beef retail sector which is playing increasingly important roles within the beef industry. This will however come at a premium to cover the extra costs of beef processing (GEMS1, 2012) and more importantly, the success of such a programme will depend on the willingness of the consumers to pay for the extra costs arising from inspecting and certifying the quality of beef.

Several studies have examined different aspects of the beef industry in Nigeria; Oyediran (2015) investigated the impact of veterinary inspection practices on beef quality, Adeyemo (2002) examined the environmental implications of the unhygienic operation of a city abattoir, and Oluwafemi et al. (2013) reviewed beef processing practices. Only a few (Ehirim, 2015) examined the issue of beef quality from the demand side. However, none has disaggregated the analysis to examine the factors which influence consumers' decision to buy safe beef as well as what factors motivate the amount they will pay for safe beef. This paper therefore examined consumers' willingness to pay for safe beef in Oyo State. Specifically, we investigated the level of consumers' awareness of safe beef, identified the factors which influence both the consumers' willingness to pay for safe beef and the amount consumers will pay for safe beef as well as the average amount consumers will pay for a kilogramme of safe beef in the study area. The rest of this paper is organized as follows: section two describes survey design, data collection and the estimation methodology. This is followed by a discussion of the results of analysis in section three. The paper ends with a section on concluding remarks. 


\section{MATERIALS AND METHODS}

The study was carried out in Ibadan Metropolis of Oyo State, Nigeria. Oyo State is located in the south-west geopolitical zone of Nigeria. The state covers a total of $28,454 \mathrm{~km}^{2}$ with a longitude and latitude of $8.1196^{\circ} \mathrm{N}, 3.4196^{\circ}$ E respectively and a population of 5.592 million (NPC, 2010). The capital of Oyo state is Ibadan. The city is located at the edge of the savannah and is the third largest metropolitan area, by population, in Nigeria after Lagos and Kano; with a population of over 3 million (Makama, 2007). Ibadan is located between latitude 7.23N and longitude 3.55E. Ibadan is located in south-western Nigeria, $128 \mathrm{~km}$ inland north-east of Lagos and $530 \mathrm{~km}$ southwest of Abuja, the federal capital, and is a prominent transit point between the coastal region and the areas to the north. Ibadan had been the centre of administration of the old western region since the days of the British colonial rule, and parts of the city's ancient protective walls still stand to this day. The city's total area is $1,190 \mathrm{sq} . \mathrm{mi}(3,080 \mathrm{~km})$.

There are eleven (11) local government areas in Ibadan metropolis. Five of the local governments are urban which encompass Ibadan North, Ibadan North-East, Ibadan Northwest, Ibadan south-east and Ibadan south-west. The remaining six are rural local governments covered by Akinyele, Egbeda, Ido, Lagelu, Ona Ara and Oluyole. The city is dominated by the Yorubas among other resident tribes while religion is mainly Christianity, Islamic and traditional religion background.

Primary data was used in this study and collected from beef consumers selected through a multi-stage sampling procedure. The first stage was the random selection of Ibadan North Local Government Area (LGA), followed by the second stage which involved the random selection of four out of the twelve wards in Ibadan North LGA. The final stage was the random selection of 40 beef consumers from each ward, making up a total of 160 respondents. However, only 150 beef consumers were used for analysis due to incomplete data. Information on consumers' socio-economic characteristics (such as sex, occupation, age, religion, marital status among others), the level of awareness and perception of safe beef were collected using structured questionnaires. Data was analysed using the double bounded dichotomous choice, contingent valuation method.

The double bounded dichotomous choice approach to contingent valuation was used to elicit information on consumers' willingness to pay for safe beef. It has been shown that the "doublebounded" approach is asymptotically more efficient than the conventional, "single- bounded" approach (Hanemann et al., 1991). This method is also preferable to triple or higher bids. Cooper \& Hanemann, 1995 showed that the additional statistical efficiency gains in estimating mean WTP from adding the third or fourth follow up bid is relatively small and it can increase the chance of inducing response effects.

Consumers were offered several opening bids ranging between $\$ 1000$ to $\$ 1600$. If a consumer accepts the first bid, the second bid is raised by $\$ 200$. If the second higher bid is accepted, that value is considered as the WTP. However, if the consumer rejects the higher bid, the original bid offered is considered as the WTP. Also, if the consumer rejects the initial bid, then the bid is lowered by 200 . If the lower bid is accepted, the value is considered as the WTP. If the second lower bid is however rejected, the consumer is asked to provide an estimate of the maximum amount she/he is willing to pay for safe beef. Note that in this process, each individual provides one of the four responses: yes-yes, yes-no, no-yes, no-no.

Heckman's two-stage model was used to analyse the determinants of consumer' willingness to pay for safe beef as well as the amount consumers will pay for a kilogramme of packed safe 
beef. The first stage is a probit model which defines whether a consumer will pay for safe beef or not, while the second stage is an ordinary least squares regression model to determine the amount consumers will pay for safe beef.

According to Heckman (1979), consumers' willingness to pay (WTP) for safe beef is defined as:

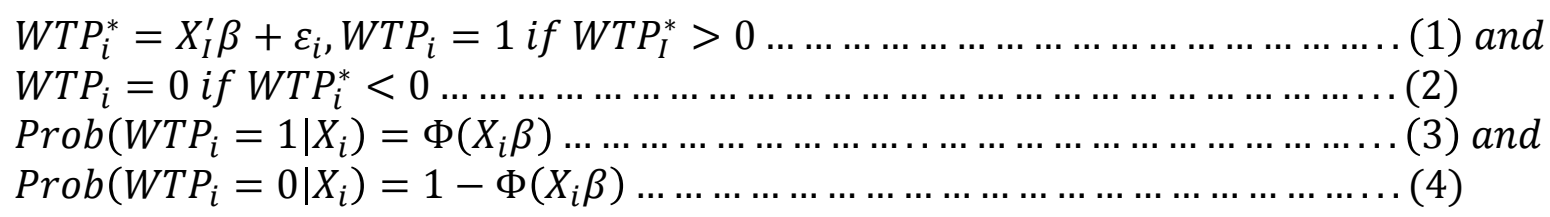

The consumers' willingness to pay for safe beef is explicitly modeled as:

$Y=\beta_{0+} \beta_{1} X_{1}+\beta_{2} X_{2}+\beta_{3} X_{3}+\cdots+\varepsilon_{i}$

Where $\mathrm{Y}=$ consumer willingness to pay (yes=1, 0 otherwise)

$\mathrm{X}_{1}=$ age (in years)

$\mathrm{X}_{2}=\operatorname{sex}$ (male $=1,0$ otherwise)

$\mathrm{X}_{3}=$ educational level (years spent in education)

$\mathrm{X}_{4}=$ household size

$\mathrm{X}_{5}=$ consumers' awareness of safe beef (yes $=1,0$ otherwise)

$\mathrm{X}_{6}=$ frequency of purchase (number of times per week)

$\mathrm{X}_{6}=$ consumers' knowledge of safe beef (yes=1, 0 otherwise)

$\mathrm{X}_{7}=$ monthly income of the consumer (Naira)

$\mathrm{X}_{8}=$ marital status (married $=1,0$ otherwise)

$\mathrm{X}_{9}=$ consumers' perception of quality index

Consumers' perception of quality index is an indicator of beef quality as assessed by the consumers. It is based on four beef characteristics namely beef colour, odour, freshness, and texture. Consumers are scored on a scale of 1-5 depending on their use of each characteristic to judge beef quality. The index is thereafter calculated by dividing the sum of the scores obtained by 20 , the maximum obtainable. The index therefore ranges from 0 to 1 with values closer to 1 indicating higher beef quality perception by the consumers.

The second stage linear regression model is represented as:

$$
W T P=w_{i}^{\prime} \delta+u_{i}
$$

Where $W T P$ is the amount consumers will pay for safe beef and it is observed only if $Y_{i}=1$,

$\mathrm{W}_{1}=$ age of the consumer (years)

$\mathrm{W}_{2}=\operatorname{sex}$ (male $=1,0$ otherwise)

$\mathrm{W}_{3}=$ years of education (years)

$\mathrm{W}_{4}=$ household size

$\mathrm{W}_{5}=$ frequency of purchase

$\mathrm{W}_{6}=$ consumers' awareness of safe beef

$\mathrm{W}_{7}=$ monthly income (naira)

$\mathrm{W}_{8}=$ quality perception index

$\mathrm{W}_{9}=$ lambda (Inverse Mill's ratio)

The coefficient on the Inverse Mill's ratio allows for a test of selection bias. If the regression coefficient of the inverse mills ratio is significant, it means there is sample selection bias and 
the use of ordinary least squares will produce biased estimates of the amount farmers will pay for rainfall index insurance.

The error terms $\varepsilon_{i}$ and $u_{i}$ are assumed to have a bivariate normal distribution with zero means and correlation coefficient, $\rho\left(\varepsilon_{i}, u_{i} \sim \operatorname{bvn}\left[0,0,1, \sigma_{\varepsilon}\right]\right)$.

The mean willingness to pay for safe beef is estimated as:

$E\left[\left(W T P \mid Y_{i}=1, W_{i}, X_{i}\right)=W_{i}^{\prime} \beta+\rho \sigma_{u} \lambda\left(W_{i}^{\prime} \delta\right)\right.$

Where $\lambda$ is the Inverse Mill's ratio.

\section{RESULTS AND DISCUSSION}

Table 1 presents the results description of socioeconomic characteristics of the beef consumers in the study area. The mean age is $37( \pm 11.6)$ years and most of the consumers are females $(68 \%)$ and married $(72.7 \%)$ with a mean household size of $4 \pm 2.25$ members. This suggests that majority of the beef consumers are active working class people who can afford beef in their diets. Most beef consumers are well educated with an average of about 17 years of schooling. Consequently, it was observed that that most of the people who purchase beef have good-salaried jobs, given the mean monthly income of $\$ 106,805.33$ (\$305.16). Although there is a wide gap in the income of beef consumers as indicated on Table 1 which shows that about a quarter of the respondents belong to the highest and lowest income categories respectively. Results also indicate that majority of the consumers are civil servants (44\%) and purchase beef about four to five times in a month (34\%). 
Table 1: Selected socioeconomic characteristics of beef consumers

\begin{tabular}{|c|c|c|}
\hline Variable & Frequency & Percentage \\
\hline \multicolumn{3}{|l|}{ Age (years) } \\
\hline$<30$ & 52 & 34.7 \\
\hline $31-40$ & 52 & 34.7 \\
\hline $41-50$ & 24 & 16.0 \\
\hline $51-60$ & 17 & 11.3 \\
\hline$>60$ & 5 & 3.3 \\
\hline Mean & 37.15 & \\
\hline S.D. & 11.62 & \\
\hline \multicolumn{3}{|l|}{ Marital status } \\
\hline Married & 109 & 72.7 \\
\hline Single & 41 & 27.3 \\
\hline \multicolumn{3}{|l|}{ Gender } \\
\hline Male & 48 & 32 \\
\hline Female & 102 & 68 \\
\hline \multicolumn{3}{|l|}{ Years of education } \\
\hline$<6$ & 4 & 2.7 \\
\hline $7-12$ & 20 & 13.3 \\
\hline $13-18$ & 83 & 55.3 \\
\hline$>19$ & 43 & 28.7 \\
\hline Mean & 16.89 & \\
\hline S.D & 4.15 & \\
\hline \multicolumn{3}{|l|}{ Income (Naira) } \\
\hline$<20000$ & 41 & 27.3 \\
\hline $21000-40000$ & 27 & 18.0 \\
\hline $41000-60000$ & 29 & 19.3 \\
\hline $61000-80000$ & 8 & 5.3 \\
\hline $81000-100000$ & 5 & 3.3 \\
\hline$>100000$ & 40 & 26.7 \\
\hline Mean & 106805.33 & \\
\hline S.D & 149125.51 & \\
\hline \multicolumn{3}{|l|}{ Household size } \\
\hline$<2$ & 47 & 31.3 \\
\hline $3-5$ & 67 & 44.7 \\
\hline $6-8$ & 33 & 22.0 \\
\hline$>9$ & 3 & 2.0 \\
\hline Mean & 3.87 & \\
\hline S.D & 2.25 & \\
\hline \multicolumn{3}{|c|}{ Frequency of beef purchase } \\
\hline Once per month. & 43 & 28.7 \\
\hline 2 to 3 times per month. & 35 & 23.3 \\
\hline 4 to 5 times per month. & 51 & 34.0 \\
\hline$>5$ times per month & 21 & 14.0 \\
\hline \multicolumn{3}{|l|}{ Occupation } \\
\hline Civil servant & 66 & 44.0 \\
\hline Self-employed & 45 & 33.0 \\
\hline Private employed & 32 & 21.3 \\
\hline Artisan & 2 & 1.3 \\
\hline Others & 5 & 3.3 \\
\hline
\end{tabular}

Source: Field Survey, 2016.

Sample size $=\mathbf{1 5 0}$

From the results shown on Table 2, it can be seen that majority of beef consumers (92\%) are aware that not all beef sold at various outlets are safe for consumption. This is not surprising given the mean years of education of the beef consumers. Many of them are aware of the risks of beef contamination due to exposure. With regards to knowledge on the human version of mad cow disease called variant Creutzfeldt - Jakob disease (vCJD), almost 95\% of the beef consumers were aware that consumption of beef products infected with mad cow disease can 
lead to vCJD. This may be due to the wide coverage which an outbreak of the disease in Europe received upon its discovery in the year 1996 (Setbon et al., 2005). Moreover, almost a third of the beef consumers obtain information about the health risks of unsafe beef through a combination of mass media platforms (such as radio, television, and newspapers), family and friends and from health workers and the food and drugs regulatory agency (NAFDAC).

Table 2: Awareness of consumers about safe beef

\begin{tabular}{lll}
\hline Awareness & Frequency & Percentage \\
\hline Awareness of safe beef & 135 & \\
Yes & 6 & 90.0 \\
No & 9 & 4.0 \\
Uncertain & 150 & 6.0 \\
Total & & 100 \\
Awareness that unsafe beef consumption may lead to & & \\
mad cow disease in humans & 142 & \\
Yes & 5 & 94.7 \\
No & 3 & 3.3 \\
Uncertain & 150 & 2.0 \\
Total & & 100 \\
Source of safe beef information & 40 & \\
Mass Media & 20 & 26.7 \\
NAFDAC/Health Workers & 41 & 13.3 \\
Friends and Family & 49 & 27.3 \\
All of the Above & 150 & 32.7 \\
Total & 100.0 \\
\hline
\end{tabular}

Source: Field Survey, 2016.

Regarding the consumers' willingness to pay, Table 3 shows that over $80 \%$ of the consumers indicated a willingness to pay for safe beef. The observed willingness to pay can be attributed to the high level of awareness about the dangers posed by consumption of infected beef in addition to the high level of education of the beef consumers. It is therefore reasonable for the consumers to be positive about paying for safe beef in order to avoid the harmful effects of consuming contaminated beef. This result confirms the assertion by (GEMS1, 2012) that increasing demand for meat by consumers is accompanied by improved quality requirements.

The responses of the consumers to the bidding game are as shown in Table 4. Only respondents who indicated a willingness to pay were subjected to the interactive bidding game. About one -thirds of the consumers who indicated a willingness to pay agreed to pay even at higher prices. This shows that consumers who place a high premium on safe beef are prepared to pay a higher amount for the product. However, majority of the consumers only agreed to pay only after the opening bid was lowered.

Table 3: Distribution of consumers' willingness to pay for safe beef

\begin{tabular}{lll}
\hline Response & Frequency & Percentage \\
\hline Yes & 123 & 82 \\
No & 27 & 18 \\
Uncertain & 0 & 0 \\
Total & 150 & 100.0 \\
\hline
\end{tabular}

Source: Field Survey, 2016. 
Table 4: Distribution of beef consumers based on responses to bidding game

\begin{tabular}{ccc}
\hline Responses & Frequency & Percentage (\%) \\
\hline yes-yes (yy) & 43 & 34.96 \\
yes-no (yn) & 17 & 13.82 \\
no-yes (ny) & 54 & 43.90 \\
no-no (nn) & 9 & 7.32 \\
\hline Total & 123 & 100.0
\end{tabular}

Source: Field survey, 2016

Table 5 shows the determinants of consumers' willingness to pay for safe beef. The chi-square value is 20.00 and it is significant at the $5 \%$ level of significance which indicates that the model is well fitted. The marginal effect shows the effect of a one unit change in the explanatory variable on the probability that a consumer will buy safe beef. The results indicate that awareness about safe beef is another factor which significantly affects consumers' willingness to pay for safe beef. The estimated coefficient is positive and significant at $1 \%$ level of significance, meaning that being aware of the deleterious effects of quality impaired beef increases the probability that a consumer will buy safe beef by $35.1 \%$. This agrees with the findings reported by $\mathrm{Xu}$ and $\mathrm{Wu}(2010)$ that consumers who are aware of the health risks posed by quality impaired food items are more likely to pay for certified food. Further, the gender of the beef consumer significantly influences consumers' willingness to pay for safe beef. The estimated coefficient for gender is also positive and significant at $10 \%$ level of significance. This means that the probability of females paying for safe beef is $12.4 \%$ higher than males. This may be because females are largely responsible for the shopping decisions in most households and are therefore more likely to be interested in the quality of beef they purchase. This result is in agreement with the findings of Ehirim (2013) that women are more likely to buy safe beef than men.

Table 5: Determinants of consumers' willingness to pay for safe beef

\begin{tabular}{|c|c|c|c|c|}
\hline Variable & Coefficient & Standard error & z-value & Marginal effects \\
\hline Age & 0.0023 & 0.0172 & 0.13 & 0.0005 \\
\hline Gender & $0.5361^{*}$ & 0.2891 & 1.85 & 0.1242 \\
\hline Level of education & -0.0436 & 0.0391 & -1.12 & -0.0101 \\
\hline Household size & -0.0670 & 0.0787 & -0.85 & -0.0155 \\
\hline $\begin{array}{l}\text { Frequency of } \\
\text { purchase }\end{array}$ & -0.0893 & 0.6003 & -0.15 & -0.0207 \\
\hline $\begin{array}{l}\text { Awareness of safe } \\
\text { beef }\end{array}$ & $1.5718^{* * *}$ & 0.4302 & 3.53 & 0.3515 \\
\hline Marital status & 0.4120 & 0.3734 & 1.10 & 0.0954 \\
\hline $\begin{array}{l}\text { Consumer's } \\
\text { knowledge }\end{array}$ & 0.5616 & 0.5640 & 1 & 0.1301 \\
\hline Monthly income & 0.1693 & 0.1570 & 1.08 & 0.0392 \\
\hline Quality perception & 0.2843 & 0.7490 & 0.38 & 0.0659 \\
\hline Constant & -2.1466 & 1.7544 & -1.22 & \\
\hline $\operatorname{LR} \chi^{2}$ & 20.00 & & & \\
\hline Prob > chi2 & 0.0293 & & & \\
\hline Log likelihood & -60.709888 & & & \\
\hline Pseudo R² & 0.1414 & & & \\
\hline
\end{tabular}

Source: Data Analysis, 2016

$*, * * *$ represent levels of significance at $10 \%$ and $1 \%$ respectively. 
The results of the second stage regression of the Heckman model which shows the factors which influence the amount consumers will pay for safe are presented in Table 6 . The chi square value of 19.22 is significant at $5 \%$ level of significance which indicates a good fit of the model. The lambda, which is the coefficient of the inverse mill's ratio is not significant which means that there is no selectivity bias in the sample. Findings reveal that the age of the beef consumer, the household size, and the frequency of purchase are the factors which determine how much consumers will pay for safe beef. The age of the consumer has a positive relationship with the amount the consumer will pay for safe beef and it is significant at the $10 \%$ level of significance. The estimated coefficient indicates that an increase of one year in the age of the consumer will increase the amount paid for safe beef by $\$ 10.97$. This may be connected with the fact that older consumers are less likely to take health related risks especially as they will have to bear the cost of treatment of any ailment arising from contaminated beef consumption. This result is however inconsistent with the study of Wu et al. (2012) which found that age has no significant impact on the amount paid for safe food products. Further, the household size has a negative relationship with the amount the consumers will pay for safe beef. Its estimated coefficient is significant at the 5\% level of significance. For each additional member in the household, the amount the consumers will pay decreases by $\$ 65.43$. This could be as a result of the increase in total household expenditure which additional household members bring. This may reduce the ability of such households to afford safe beef. The frequency of purchase is also another factor which negatively influences the amount consumers will pay for safe beef. Its estimated coefficient is significant at 5\% level of significance and indicates that frequent purchases of beef reduce the amount consumers will pay for safe beef by $\$ 23.66$. This could be explained by the fact that most beef consumers are salaried and may not be disposed to increase the amount of household food expenditure allotted to beef purchase since it is fixed. This may be particularly for consumers who have not had any major health incident and assume that assessment of the beef by physical appearance is sufficient, thus; showing low valuation of safe beef. This result is consistent with the findings of Angulo and Gill (2007) that high frequency of buying beef reduces the premium paid for safe beef. 
Table 6: Factors influencing the amount consumers will pay for safe beef.

\begin{tabular}{lcccc}
\hline Variable & Coefficient & Standard Error & z-value & $\mathbf{P}>|\mathbf{z}|$ \\
\hline Age & $10.96532^{*}$ & 6.29119 & 1.74 & 0.081 \\
Gender & -145.27 & 128.412 & -1.13 & 0.258 \\
Years of education & 11.8303 & 16.1378 & 0.73 & 0.464 \\
Household size & $-65.42751^{* *}$ & 28.9433 & -2.26 & 0.024 \\
Frequency of purchase & $-423.658^{* *}$ & 202.358 & -2.09 & 0.036 \\
Consumers' knowledge & -271.95 & 175.146 & -1.55 & 0.12 \\
safe beef & & & & \\
Monthly income & -26.189 & 60.5301 & -0.43 & 0.665 \\
Quality perception & 295.313 & 305.995 & 0.97 & 0.334 \\
Constant & 1204.27 & 679.896 & 1.77 & 0.077 \\
Lambda & 13.1596 & 313.41 & 0.04 & \\
Rho & 0.0234 & & & \\
Sigma & 562.299 & & & \\
Wald chi 2(8) & 19.22 & & & \\
Prob>chi2 & 0.0137 & & & \\
\hline
\end{tabular}

Source: Data Analysis, 2016.

$*, * *$ represent levels of significance at $10 \%$ and $5 \%$ respectively.

The average amount consumers will pay for safe beef is shown on Table 7. It is estimated from the fitted values of the Heckman model and the bounds are calculated using bootstrapping method. The result shows that the consumers will pay $\$ 26.06$ for a kilogramme of safe beef.

Table 7: Mean willingness to pay estimate

\begin{tabular}{llll}
\hline Estimate & Observed coefficient & Lower bound & Upper bound \\
\hline Mean & $\$ 962.68$ & $\$ 926.06$ & $\$ 999.31$ \\
\hline
\end{tabular}

Source: Data Analysis, 2016.

\section{CONCLUSION AND RECOMMENDATIONS}

The study established that beef consumers are willing to pay for safe beef nevertheless; beef consumers who are aware of safe beef have a higher probability of being willing to pay for safe beef. Also, female beef consumers have a higher probability of being willing to pay for safe beef than males. Although, mean willingness to pay is about 962.68 , the actual amount a beef consumer is willing to pay for safe beef is influenced by age, household size and frequency of purchase. Therefore, policy options should encourage increased enlightenment programs on safe beef. Also safe beef entrepreneurs should target the female folk with respects to advertisement and sales activities. Finally, a mechanism of beef certification and quality labelling should be put in place in order to assist safety-aware beef consumers in ascertaining the quality of the beef products they purchase.

\section{References}

Adeyemo, K.O. 2002. Unhygienic operation of a city abattoir in south-western Nigeria: Environmental implications. African Journal of Environmental Assessment and Management. 4(1):23-28.

Angulo, A.M. and J.M. Gil 2007. Risk perception and consumer willingness to pay for certified beef in Spain, Food Quality and Preference, 18: 1106-1117. 
Benard, C., B. Bonnet, and B. Guivert 2010. Demand for farm animal products in Nigeria: An opportunity for Sahel countries, Grain de Sel, 51: 14-15.

Ehirim, N.C., L.O.E. Nwauwa, and E.E. Ikheloa. 2013. Determinants of consumer preference for safe beef in Delta State, Nigeria, Wudpecker Journals of Agricultural Research, 2(3): 073-079.

FAO 2014 Food and Agricultural Organisation World Food Outlook 2014. Accessed at http://www.fao.org/ag/againfo/themes/en/meat/background.html

Growth and Employment in States Programme 2012. Transforming the Nigerian beef industry. Retrieved from http://gemsnigeria.com/wordpress/wp-content/uploads/2012/12/GEMS1Brief_BeefIndustryTransformation4page.pdf.

Hanemann, M., J. Loomis, B. Kanninen 1991. Statistical Efficiency of Double-bounded Dichotomous Choice Contingent Valuation, American Journal of Agricultural Economics, 73, 1255-1263.

Heckman, J. 1979. Sample selection bias as a specification Error. Econometrica, (47): 153-161.

Makama, S.I.D., 2007. Report of Nigeria's National Population Commission on the 2006 Census, 206-210.

NBS - National Bureau of Statistics, 2012. Poverty Profile for Nigeria. National Bureau of Statistics Federal Republic of Nigeria, Abuja.

Nwanta, J.A., J.I. Onunkwo, V.E Ezenduka, P.O. Phil-Eze, and S.C. Egege. 2008. Abattoir operations and waste management in Nigeria: A review of challenges and prospects, Sokoto Journal of Veterinary Sciences, 7 (2): 60-67.

Olaoye, O.A and A.A. Onilude 2010. Investigation on the potential application of biological agent in the extension of shelf life of fresh beef in Nigeria, World Journal of Microbiology and Biotechnology, 26(8): 1445-1454.

Oluwafemi, R.A., O.M. Edugbo, and A.J. Akinyeye 2013. Meat quality, nutrition, security and public health: A review of beef processing practices in Nigeria. African Journal of Food Science and Technology, 4(5): 96-99.

Oyediran, W.O. 2015. Assessment of veterinary inspection practices on quality of beef produced in Ibarapa Central Local Government Area of Oyo State, Nigeria. International Journal of Veterinary Science Research, 1(2): 36-45.

Setbon, M., J. Raude, C. Fischer, and A. Flahault 2005. Risk perception of the Mad Cow Disease in France: Determinants and consequences, Risk Analysis, Vol. 25: 813-826.

Umoh J.U. 2002. Critical control point of beef products. www.thisdayonline.com/archive/2002/02/19/20020219bus20.html, retrieved 2002-02-19.

Verbeke, W. and R.W. Ward 2006. Consumer interest in information cues denoting quality, traceability and origin: an application of ordered probit models to beef labels, Food Quality and Preference, 17(6): 453-467.

Wu, L., L. Xu, D. Zhu, and X. Wang 2012. Factors affecting consumer willingness to pay for certified traceable food in Jiangsu Province of China, Canadian Journal of Agricultural Economics, 00: 1-17.

$\mathrm{Xu}$, L. and L. Wu 2010. Food safety and consumer willingness to pay for certified traceable food in China, Journal of Science, Food and Agriculture, 90: 1368-1373. 